九州大学学術情報リポジトリ

Kyushu University Institutional Repository

\title{
Effects of Straw Incorporation Time on Rice Yield and Methane Emissions from Sandy Loam Paddy Fields
}

\section{LUYIMA, Deogratius}

Department of Bio-Environmental Chemistry, College of Agriculture and Life science, Chungnam National University

JEONG, Hyun-Cheol

office of the administrator, RDA

\section{LEE, Jae-Han}

Department of Bio-Environmental Chemistry, College of Agriculture and Life science, Chungnam National University

KIM, Su-Hun

Department of Bio-Environmental Chemistry, College of Agriculture and Life science, Chungnam National University

他

https://doi.org/10.5109/2339106

出版情報: 九州大学大学院農学研究院紀要. 64 (2)，pp.213-218，2019-09-02. Faculty of Agriculture, Kyushu University

バージョン :

権利関係 : 


\title{
Effects of Straw Incorporation Time on Rice Yield and Methane Emissions from Sandy Loam Paddy Fields
}

\author{
Deogratius LUYIMA ${ }^{1 \dagger}$, Hyun-Cheol JEONG ${ }^{2 \dagger}$, Jae-Han LEE ${ }^{1}$, Su-Hun KIM ${ }^{1}$, Yoshiyuki SHINOGI \\ Chang Hoon $\mathrm{LEE}^{4 *}$ and Taek-Keun $\mathrm{OH}^{1 *}$
}

\author{
Science for Bioproduction Environment, Faculty of Agriculture, Kyushu University, \\ Motooka 744, Nishi-ku, Fukuoka city 819-0395, Japan \\ (Received May 8, 2019 and accepted May 8, 2019)
}

\begin{abstract}
Rice paddy fields are a significant source of anthropogenic methane emitted into the atmosphere with several studies reporting heightened emissions after rice straw incorporation into the paddy soils. These emissions may differ owing to the time of straw incorporation into the field, i.e. either during the fallow or growing seasons. In the current study, we evaluated the emissions from straw incorporated during both the rice growing and fallow seasons over a three-year period. Additionally, effects on soil chemical properties and rice yields were assessed. The treatments involved incorporating straw a few days before the main rice growing season (spring straw), incorporation of straw during the fallow season, i.e. immediately after the autumn harvest (autumn straw) and the control with no straw incorporated at all. The weekly emissions from both spring and autumn straw applications decreased with the progression of the experiment, i.e. the emissions went on reducing season after season until the end of the experiment. The emissions from the control remained mostly constant throughout the experiment. Of the two straw application times, autumn application resulted in the lowest methane emissions. The effects of all the treatments on soil chemical properties were mostly adverse while the total rice yields slightly increased over time in the straw amended soils. The adverse effects on soil chemical properties might have been caused by the incomplete decomposition of rice straw given that a single rice growing season may not be enough for its complete dissolution.
\end{abstract}

Key words: Autumn straw incorporation, Methane emissions, Sandy loam soil, Spring straw incorporation

\section{INTRODUCTION}

Rice paddies are a crucial source of atmospheric methane (Liou et al., 2003; Jacobson 2005) contributing approximately 20-40 $\mathrm{Tg}$ of $\mathrm{CH}_{4}$ year ${ }^{-1}$ which accounts for about $20 \%$ of the anthropogenic $\mathrm{CH} 4$ emitted globally (Tariq et al., 2017). The rapidly increasing global population requires similar increases in rice production which is one of the three important kinds of cereal that account for more than $50 \%$ of the global food calories, the others being maize and wheat (Fischer et al., 2009; CalabiFloody et al., 2017). This increased rice production will automatically heighten the methane emission problem especially if the existing farming practices continue. (Neue et al., 1996; Liou et al., 2003).

Management of straw after rice harvests poses an enormous challenge to all rice farmers around the globe (Tariq et al., 2017). In many countries, farmers burn these crop residues openly in the rice fields (Gadde $e t$

Department of Bio-Environmental Chemistry, College of Agriculture and Life science, Chungnam National University, Daejeon 305-764, Korea

${ }^{2}$ Office of the administrator, RDA, 300 Nongsaengmyeong-ro, Wansan-gu, Jeonju-si, Jeollabuk-do 54875, Korea

${ }^{3}$ Science for Bioproduction Environment, Faculty of Agriculture, Kyushu University, Motooka 744, Nishi-Ku, Fukuoka city 819-0395, Japan

${ }^{4}$ Department of Fruit Science, Korea National College of Agriculture and Fisheries, Jeonju 54874, Korea

$\dagger$ These two authors contributed equally to this work and should be considered co-first authors

* Corresponding author (E-mail: ok5382@cnu.ac.kr) (T.K. OH)

* Corresponding author (E-mail: chlee915@korea.kr) (C.H. Lee) $a l ., 2009)$ as the quickest and inexpensive way of disposing of them and preparing for the next crop growing season (NDEP, 2003; Gadde et al., 2009; Webb et al., 2009). However, open burning of crop residues is associated with a miscellany of environmental issues for example emissions of heavy metals and dioxins (Webb et al., 2009), large quantities of $\mathrm{CO}, \mathrm{CO}_{2}$, particulate matter and volatile hydrocarbons into the air (EIA, 2008). That is in addition to the loss of valuable crop nutrients in gaseous forms (Haider, 2013). Due to these environmental effects, rice straw burning is currently outlawed in many countries.

Incorporating rice straw into the soil is, therefore, becoming a common agronomic practice among rice farmers although several studies for example by Kim eet al. (2018a), Wang et al. (2015) and others have reported methane emission increases from paddy fields due to this style of straw management. The current study thus aimed to quantify methane emissions resulting from rice straw incorporated into the sandy loam paddy soil in different seasons of the year, i.e. autumn and spring and to assess how these incorporation time variations affect both the rice yield and soil chemical properties.

\section{MATERIALS AND METHODS}

\section{Field Experimental Set-Up}

The experiments were conducted for three years (2016-2018) in the paddy fields of Noeun-dong ( $36^{\circ} 22^{\prime}$ 23.7”N, 127¹9'39.5”E), Yuseong-Gu, Daejeon, South Korea. The straw was incorporated into the soil at different times of the year, i.e. autumn (immediately after 
harvesting) and spring (straw left on the soil surface during the winter season and incorporated in the soil in the spring season). The straw was incorporated at a rate of $8 \mathrm{Mg} \mathrm{ha} \mathrm{H}^{-1}$. The chemical fertiliser of NPK was added uniformly to all plots at rates of 90,45 and $57 \mathrm{~kg} \mathrm{ha}^{-1}$ respectively. The control was made of plots that only received chemical fertilisation, i.e. with no straw added. The variety of rice cultivated was the medium to late maturing Sindong-jinbyeo. Twenty-one days (old) seedling were transplanted into the flooded paddies with harvesting coming 132 days later. The paddies were only flooded during the rice growing season after which they were drained to dry. It's important to note that the Korean rice growing season usually starts in late May or early June and ends in October.

\section{Gas Sampling and Analysis}

Methane gas emitted during the rice growing seasons was estimated by a closed-chamber method (Rolston, 1986; Ali et al., 2009). The chambers were made from acrylic glass with a base of $60 \mathrm{~cm} \times 60 \mathrm{~cm}$ and a height of $120 \mathrm{~cm}$ for each of them. Methane was sampled once every week throughout the rice-growing season; however additional samplings were done owing to the prevailing weather conditions. The gas samples were collected in $60 \mathrm{ml}$ polypropylene syringes $30 \mathrm{~min}$ after closing the chamber between 11:00 am and 12:00 pm as stipulated by Pramanik and Kim (2013). Methane concentrations in the collected gas samples were measured by gas chromatography using an Agilent $6890 \mathrm{~N}$ system equipped with fused silica capillary column $(30 \mathrm{~m} \times 0.53 \mathrm{~mm})$ and a flame ionisation detector (FID). The oven and detector temperatures were adjusted to $100^{\circ} \mathrm{C}$ and $250^{\circ} \mathrm{C}$, respectively. Hydrogen $\left(\mathrm{H}_{2}\right)$ and nitrogen $\left(\mathrm{N}_{2}\right)$ were used as the burning and carrier gases, respectively. Emission rates from the sandy loam soils were calculated basing on the increase in methane concentration per unit surface area of the chamber within a specific time interval. A closed-chamber equation described by Rolston (1986) was applied for the methane flux estimations as follows.

$$
F=\rho \times(b / a) \times(\Delta c / \Delta t) \times(273 / T)
$$

Where $\mathrm{F}$ represents the $\mathrm{CH}_{4}$ flux $\left(\mathrm{mg} \mathrm{m}^{-2} \mathrm{~h}^{-1}\right), \rho$ is the gas density which stands at $0.714 \mathrm{mg} \mathrm{cm}^{-3}$, b is the chamber's volume $\left(\mathrm{m}^{3}\right)$, a is the chamber's surface area $\left(\mathrm{m}^{2}\right), \Delta \mathrm{c} / \Delta \mathrm{t}$ is the rate of increase of $\mathrm{CH}_{4}$ concentration in the chamber ( $\mathrm{mg} \mathrm{m}^{-3} \mathrm{~h}^{-1}$ ), and $\mathrm{T}$ is the absolute tempera- ture. $\mathrm{T}$ is the Kelvin temperature obtained by adding the mean temperature $\left({ }^{\circ} \mathrm{C}\right)$ of the chamber to 273 . The total $\mathrm{CH}_{4}$ flux for each of the full growing season was computed from the equation proposed by Singh et al. (1999) as indicated below;

$$
T F=\sum_{i}^{n}\left(F_{i} \times D_{i}\right)
$$

TF stands for Total methane gas flux; $\mathrm{F}_{\mathrm{i}}$ is the $\mathrm{CH}_{4}$ emission flux $\left(\mathrm{gm}^{-2} \mathrm{~d}^{-1}\right)$ in the $i^{\text {th }}$ sampling interval, $\mathrm{D}_{\mathrm{i}}$ represents the number of days in the $i^{\text {th }}$ sampling interval, while $n$ represents the number of sampling intervals.

\section{Soil Analysis}

The soil was sampled using a zigzag pattern, with the soil cores picked up to a depth of $15 \mathrm{~cm}$. Air-dried samples were sieved through a $2 \mathrm{~mm}$ strainer and then analysed following the Soil and Plant Analysis Methods (NIAST, 2000) established by the Rural Development Agency of Korea (RDA). Soil pH and electrical conductivity (EC) were determined with a $\mathrm{pH}$ and EC meter (ORION Versa Star Pro, Thermo Scientific Inc., USA) after extraction with distilled water in a ratio of $1: 5$ (v/w), available phosphorus was measured by the Lancaster method using a UV-VIS spectrophotometer (Evolution 300, Thermo Scientific Inc., USA). Exchangeable cations of $\mathrm{K}^{+}, \mathrm{Ca}^{2+}$ and $\mathrm{Mg}^{2+}$ were analysed using inductively coupled plasma optical emission spectrometry (ICP-OES; GBC Scientific, Australia) after leaching with $1 \mathrm{~N} \mathrm{NH}_{4} \mathrm{OA}_{\mathrm{C}}$ solution at a neutral $\mathrm{pH}(\mathrm{pH}$ 7.0) The total organic carbon (TC) was analyzed using an elemental analyzer-TCD (Flash EA 1112 series, CE Instruments, Italy). The soil chemical properties before the experiment are shown in table 1 below.

\section{RESULTS}

\section{Methane Emissions}

The general trend was the decreasing weekly methane emissions season after season except for the control whose weekly emissions remained almost constant throughout the experimental period. That is evidenced in the highest peak emissions (from spring straw incorporation) that stood at $1700 \mathrm{mg} \mathrm{m}^{-2} \mathrm{hr}^{-1}$ in the first season which decreased to $1500 \mathrm{mg} \mathrm{m}^{-2} \mathrm{hr}^{-1}$ in the second season with the final season registering the lowest peak value of just below $1000 \mathrm{mg} \mathrm{m}^{-2} \mathrm{hr}^{-1}$. Incorporating rice straw into the soil in spring culminated into the highest weekly emissions in all the seasons that this experiment

Table 1. Initial soil chemical properties

\begin{tabular}{lccccccc}
\hline \multirow{2}{*}{ Treatment } & $\mathrm{pH}$ & $\mathrm{EC}$ & $\mathrm{TC}$ & Avail P & & \multicolumn{2}{c}{ Ex. cation } \\
\cline { 7 - 9 } & $(1: 5)$ & $\left.(\mathrm{ds} \mathrm{m})^{-1}\right)$ & $\left(\mathrm{g} \mathrm{kg}^{-1}\right)$ & $\left(\mathrm{mg} \mathrm{kg}^{-1}\right)$ & $\mathrm{K}^{+}$ & $\mathrm{Ca}^{2^{+}}$ & $\mathrm{Mg}^{2^{+}}$ \\
\hline Control Expt & $5.62 \pm 0.01$ & $0.30 \pm 0.01$ & $7.07 \pm 0.3$ & $134.21 \pm 9.90$ & $0.57 \pm 0.08$ & $1.70 \pm 0.21$ & $0.63 \pm 0.10$ \\
Spring Straw & $5.84 \pm 0.00$ & $0.31 \pm 0.04$ & $8.66 \pm 0.5$ & $122.45 \pm 11.2$ & $0.51 \pm 0.06$ & $1.62 \pm 0.17$ & $0.69 \pm 0.14$ \\
Autumn Straw & $5.80 \pm 0.03$ & $0.33 \pm 0.01$ & $8.15 \pm 0.3$ & $143.68 \pm 14.3$ & $0.58 \pm 0.11$ & $1.81 \pm 0.14$ & $0.67 \pm 0.08$ \\
\hline
\end{tabular}

EC: Electrical conductivity, Avail. P: Available Phosphorus, TC: Carbon, Ex. Cation: Exchangeable cation 
was conducted.

On the contrary, however, weekly methane emissions from the plots whose straw was incorporated immediately after the autumn harvest were low and lower than those from the control plots in the final season of the experiment. Apart from the first season when the weekly emissions from the Autumn straw treatment exceeded those from the control, emissions from the autumn treatment in the second season were at par with those from the control plots while in the final season the control plots emitted more methane than the autumn straw plots did. Generally, the weekly emissions were high between the $2^{\text {nd }}$ and $17^{\text {th }}$ weeks in the first season, $3^{\text {rd }}$ and $15^{\text {th }}$ weeks in the second season and, $2^{\text {nd }}$ and $15^{\text {th }}$ weeks in the last season as shown in figures 1,2 and 3 below.

\section{Soil Chemical Properties and Rice Yield}

All the assessed soil chemical properties decreased except total organic carbon of the autumn straw treated soils (see table 2 below). The weight of a 1000 grains harvested from both the control and spring straw treated soils plunged season after season while those from the autumn straw treated soils increased slightly. All treatments registered modest improvements in grain filling rates as the experiment progressed while the vegetative yield as measured by the rice straw output decreased. The total grain yield from the control plots decreased from season to season until the end of the experiment. Conversely, the yield from the plots with straw incorporations gradually increased season after season until the final season (see tables 3, 4 and 5 below)

\section{DISCUSSION}

\section{Methane Emissions}

A lot of former studies have reported increased $\mathrm{CH}_{4}$ emissions on the addition of rice straw into the soil. For example, Naser et al., 2007 reported a direct correlation between the quantity of straw incorporated and methane emissions. Similar observations have also been made by Schütz et al. (1989), Sass et al. (1990), Yagi and Minami (1990) and Kongchum et al. (2006). The emissions obtained in the first season of this study concurred with those observations in a way that even though the quantity of rice straw incorporated into the soils were the same, plots with incorporated straw emitted much more methane than the control. In the second and third season of our study, it is only the plots whose straw was added in spring that emitted more methane than the control. This observation suggests that methane emissions from rice straw incorporation may be comparable to those of the control during the rice cultivation season depending on when they are incorporated into the soil.

The lower methane emissions from the autumn straw application were in line with what Wang et al. (2015) reported that incorporating rice straw early lowered the amount of methane emitted during the rice growing season. They attributed this to the partial oxidation of the straw during the fallow which reduces the

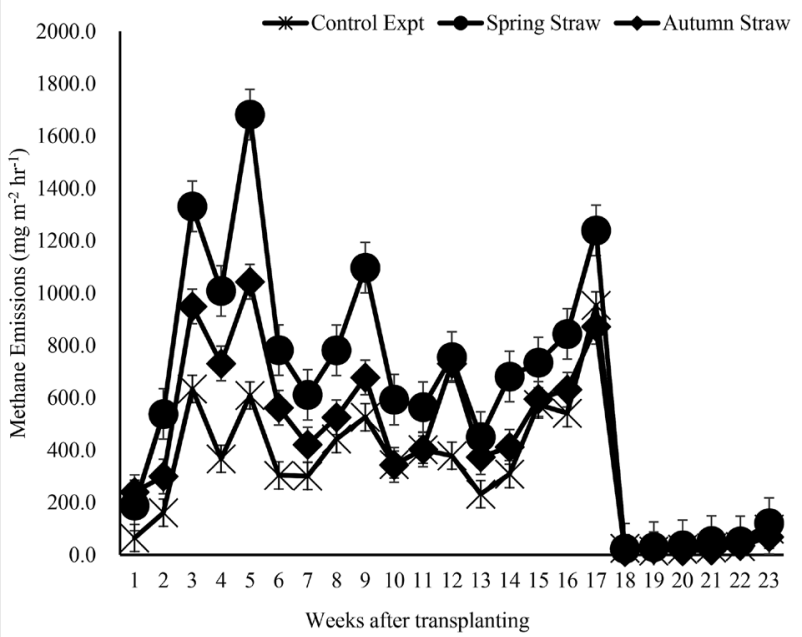

Fig. 1. Weekly emissions in the first season (2016).

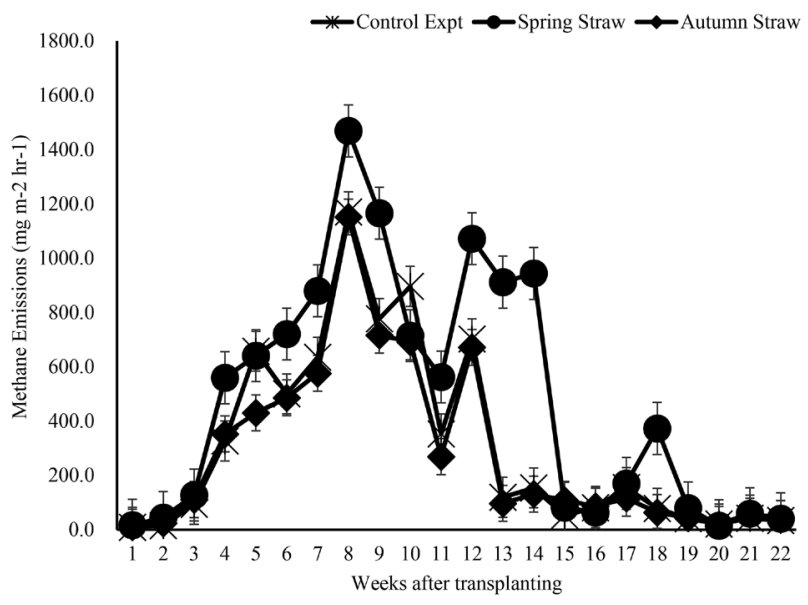

Fig. 2. Weekly emissions in the second season (2017).

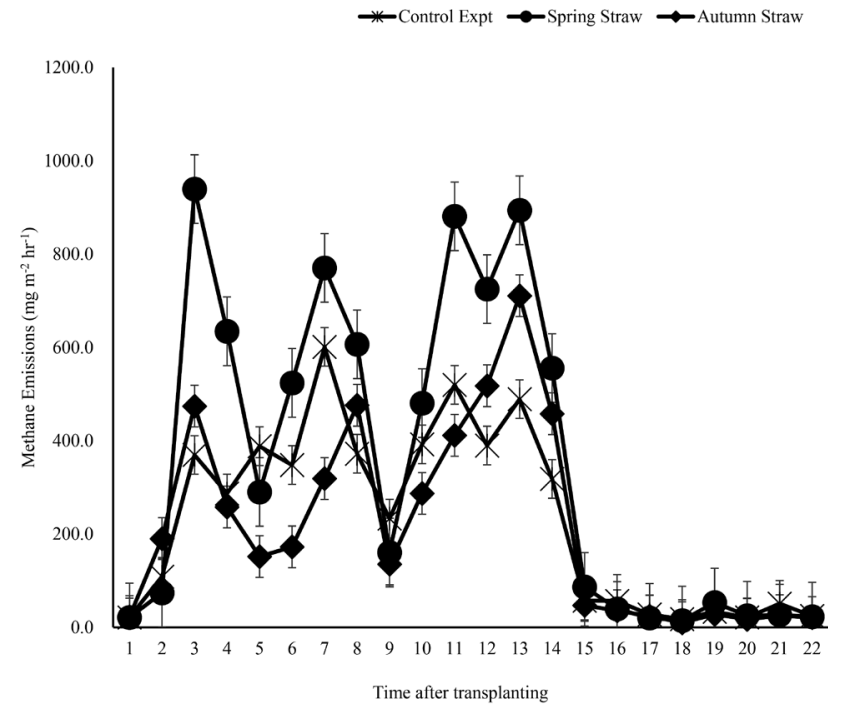

Fig. 3. Weekly emissions in the third season (2018). 
Table 2. Chemical soil properties at the end of the experiment

\begin{tabular}{cccccccc}
\hline \multirow{2}{*}{ Treatment } & $\mathrm{pH}$ & $\mathrm{EC}$ & $\mathrm{TC}$ & Avail P & & \multicolumn{2}{c}{ Ex. cation } \\
\cline { 6 - 8 } & $(1: 5)$ & $\left.(\mathrm{ds} \mathrm{m})^{-1}\right)$ & $(\mathrm{g} \mathrm{kg})$ & $(\mathrm{mg} \mathrm{kg})$ & $\mathrm{K}^{+}$ & $\mathrm{Ca}^{2^{+}}$ & $\mathrm{Mg}^{2^{+}}$ \\
\hline Control Expt & $5.4 \pm 0.01$ & $0.18 \pm 0.06$ & $7.71 \pm 0.99$ & $108.2 \pm 12.25$ & $0.12 \pm 0.04$ & $2.58 \pm 0.34$ & $0.37 \pm 0.07$ \\
Spring Straw & $5.3 \pm 0.01$ & $0.16 \pm 0.07$ & $6.55 \pm 1.12$ & $76.9 \pm 8.79$ & $0.11 \pm 0.06$ & $2.70 \pm 0.48$ & $0.31 \pm 0.04$ \\
Autumn Straw & $5.5 \pm 0.01$ & $0.2 \pm 0.06$ & $10.56 \pm 1.71$ & $136.4 \pm 19.4$ & $0.11 \pm 0.03$ & $2.77 \pm 0.39$ & $0.36 \pm 0.01$ \\
\hline
\end{tabular}

Table 3. Rice yield in the first season (2016)

\begin{tabular}{ccccc}
\hline Treatment & $\begin{array}{c}1000 \text { grain weight } \\
(\mathrm{g})\end{array}$ & $\begin{array}{c}\text { Grain Filling rate } \\
(\%)\end{array}$ & $\begin{array}{c}\text { Weight of rice straw } \\
\text { (Tonne per ha) }\end{array}$ \\
\hline Control Expt & $33.93 \pm 0.38^{\mathrm{a}}$ & $94.98 \pm 0.83^{\mathrm{b}}$ & $8.51 \pm 0.70^{\mathrm{a}}$ & $6.06 \pm 0.57^{\mathrm{ab}}$ \\
Spring Straw & $34.14 \pm 1.55^{\mathrm{a}}$ & $94.56 \pm 1.25^{\mathrm{b}}$ & $9.60 \pm 0.62^{\mathrm{b}}$ & $5.57 \pm 0.72^{\mathrm{a}}$ \\
Autumn Straw & $34.32 \pm 0.80^{\mathrm{a}}$ & $89.68 \pm 2.14^{\mathrm{a}}$ & $9.71 \pm 0.80^{\mathrm{b}}$ & $5.81 \pm 0.61^{\mathrm{a}}$ \\
\hline
\end{tabular}

Table 4. Rice yield in the second season (2017)

\begin{tabular}{|c|c|c|c|c|}
\hline Treatment & $\begin{array}{c}1000 \text { grain weight } \\
\text { (g) }\end{array}$ & $\begin{array}{c}\text { Grain Filling rate } \\
(\%)\end{array}$ & \multicolumn{2}{|c|}{ (Tonne per ha) } \\
\hline Control Expt & $32.34 \pm 0.36^{\mathrm{a}}$ & $97.20 \pm 0.66^{\mathrm{ab}}$ & $8.17 \pm 0.36^{\mathrm{a}}$ & $5.72 \pm 0.70^{\mathrm{a}}$ \\
\hline Spring Straw & $32.25 \pm 0.81^{\mathrm{a}}$ & $96.73 \pm 0.59^{\mathrm{a}}$ & $8.63 \pm 0.58^{\mathrm{a}}$ & $6.01 \pm 1.15^{\mathrm{ab}}$ \\
\hline Autumn Straw & $34.51 \pm 0.73^{\mathrm{b}}$ & $96.47 \pm 0.82^{\mathrm{a}}$ & $8.24 \pm 0.51^{\mathrm{a}}$ & $5.99 \pm 0.91^{\mathrm{ab}}$ \\
\hline
\end{tabular}

Table 5. Rice yield in the third season (2018)

\begin{tabular}{ccccc}
\hline Treatment & $\begin{array}{c}1000 \text { grain weight } \\
(\mathrm{g})\end{array}$ & $\begin{array}{c}\text { Grain Filling rate } \\
(\%)\end{array}$ & $\begin{array}{c}\text { Weight of rice straw } \\
\text { (Tonne per ha) }\end{array}$ \\
\hline Control Expt & $32.21 \pm 0.41^{\mathrm{b}}$ & $96.00 \pm 0.81^{\mathrm{ab}}$ & $8.22 \pm 0.68^{\mathrm{a}}$ & $5.89 \pm 0.94^{\mathrm{a}}$ \\
Spring Straw & $30.54 \pm 0.47^{\mathrm{a}}$ & $95.20 \pm 1.13^{\mathrm{a}}$ & $8.23 \pm 0.70^{\mathrm{a}}$ & $6.01 \pm 1.13^{\mathrm{ab}}$ \\
Autumn Straw & $35.56 \pm 0.64^{\mathrm{c}}$ & $97.10 \pm 0.78^{\mathrm{ab}}$ & $8.74 \pm 0.75^{\mathrm{a}}$ & $6.23 \pm 0.99^{\mathrm{b}}$ \\
\hline
\end{tabular}

concentration of oxidisable organic materials in the main growing season. This stance was later reiterated by Tang et al. (2016) who reported that rice straw decomposition during the fallow season resulted in a decrease in $\mathrm{CH}_{4}$ emission during the subsequent rice growing season. The decreasing pattern of emission rates observed with progression of the experiment contradicted observations made by several studies including for example by Liou et al. (2003) and Wang et al. (2015) who reported an increasing pattern of methane emissions as the experiments progressed. They argued that this was due to the accumulation of organic materials in the soil due to repeated straw applications. The emissions remained high during the rice growing season because there were no conducive conditions for methanogenesis both before transplanting and after harvesting since the paddy fields were not flooded as explained by Kim et al. (2018b).

\section{Soil Chemical Properties and Rice Yield}

Many studies for example by Roldán et al. (2003) and Dolan et al. (2006) have proved that applying crop residues to the soil greatly affects its physical and chemical properties with concomitant improvements in soil organic matter contents and nutrients (Smith et al., 1992) thus improved crop productivity. Wei et al. (2015) indicated that the incorporation of crop residues into the soil and its subsequent decomposition replenishes the soil organic matter content and also helps in the supply of essential nutrients after mineralisation. A 10-year study by Power et al. (1998) who assessed the effects of various crop residues on selected soil properties showed that the enhanced soil available nitrogen and phosphorus were directly correlated with the quantity of straw incorporated. That was later confirmed by Liu et al. (2010) who showed that long-term straw and chemical fertilisers application could increase available phosphorus and potassium concentrations in the upper soil layers in comparison with soils without straw.

The results of our current study, however, negates all the studies mentioned above because the straw incorporation mainly produced undesirable soil chemical properties. But Liu et al. (2017) stressed that straw 
incorporation could have both negative and positive effects on soil properties and crop yields depending on the incorporation method, the incorporation time, the characteristics of the straw, and the amount of fertiliser applied. For example, Dong et al. (2012) found no obvious differences in the concentrations of nitrogen and phosphorus between straw incorporation and chemical fertiliser (NPK) treatments throughout the entire experimental period in the ploughed layer of a paddy soil, possibly because the levels of $\mathrm{N}$ and $\mathrm{P}$ in the residues were small compared with the total levels in the soil. Studies by Karami et al. (2012) and Wei et al. (2015) found that enormous benefits were accruing from straw applications in the soil with positive effects on both the soil quality and crop yield. In our current study, however, rice straw application mainly evoked negative effects on almost all the soil properties studied but unexpectedly higher rice yields. The higher yields might have been a result of the chemical fertiliser (NPK) applied together with the straw.

\section{CONCLUSIONS AND RECOMMENDATIONS}

The observed negative impact of rice straw incorporation on soil chemical properties might have been due to the incomplete decomposition of the straw because rice straw has high $\mathrm{C}$ : $\mathrm{N}$ ratios and thus more time is required for its complete decomposition. These high C: $\mathrm{N}$ ratios also increase the likelihood of nitrogen immobilisation and recalcitrance of carbon contained in them (Luyima et al., 2019). Higher rice yields observed with rice straw incorporations might have resulted from the applications of NPK. With regards to methane emissions control, incorporating straw immediately after rice harvest (fallow season incorporation) results in the least emissions and is thus recommended for the sustainable management of rice straw. We recommend that long term experiments ( 10 years and above) be conducted to properly discern the extent by which straw incorporation affect soil fertility and methane emissions over a long time scale.

\section{AUTHOR CONTRIBUTIONS}

D. Luyima and H. C. Jeong wrote the paper and designed the study. S. H. Kim and J. H. LEE analyzed the data. Y. SHINOGI commented on the manuscript. T. K. OH and C. H. Lee supervised the work. All authors assisted in editing the manuscript and approved the final version.

\section{ACKNOWLEDGEMENTS}

This work was carried out with the support of the "Cooperative Research Program for Agriculture Science \& Technology Development (Project No. PJ01185505)," Rural Development Administration, Republic of Korea.

\section{REFERENCES}

Ali, M. A., Lee, C. H., Lee, Y. B and P. J, Kim. 2009. Silicate fertilisation in no-tillage rice farming for mitigation of methane emission and increasing rice productivity. Agr Ecosyst Environ., 132: $16-22$

Calabi-Floody, M., Medina, J., Rumpel, C., Condron, L. M., Hernandez, M., Dumont, M, and M. de la L, Mora 2018. Smart Fertilizers as a Strategy for Sustainable Agriculture. Advances in Agronomy, 147: 119-157

Dolan, M., Clapp, C., Allmaras, R., Baker, J and J, Molina. 2006. Soil organic carbon and nitrogen in a Minnesota soil as related to tillage, residue and nitrogen management. Soil and Tillage Research., 89(2): 221-231

Dong, W., Zhang, X., Wang, H., Dai, X., Sun, X., Qiu, W and F, Yang. 2012. Effect of Different Fertilizer Application on the Soil Fertility of Paddy Soils in Red Soil Region of Southern China. PLOS ONE, 7(9): e44504. doi: 10.1371/journal.pone.0044504

EIA, 2008. Documentation for Emissions of Greenhouse Gases in the United States 2006. Energy Information Administration (EIA), Office of Integrated Analysis and Forecasting, U.S. Department of Energy, Washington, D.C, USA

Fischer, R. A., Byerlee, D and G.O, Edmeades. 2009. In: Can technology deliver on the yield challenge to 2050? Paper Prepared for Expert Meeting on "How to Feed the World in 2050. 24-26 June 2009. FAO, Rome

Gadde, B., Bonnet, S., Menke, C and S, Garivait. 2009. Air pollutant emissions from rice straw open field burning in India Thailand and the Philippines. Environmental Pollution, 157(5): 1554-1558

Haider, M.Z., 2013. Determinants of rice residue burning in the field. J. Environ. Manage., 128: 15-21

Jacobson MZ 2005: Atmospheric Pollution: History, Science and Regulation. Cambridge University Press, New York

Karami, A., Homaee, M., Afzalinia, S., Ruhipour, H and S, Basirat. 2012. Organic resource management: Impacts on soil aggregate stability and other soil physico-chemical properties. Agric Ecosyst Environ., 148: 22-28

Kim, S. H., Lee, J. H., Lim, J. S., Shinogi, Y., Lee, C. H and T. K, Oh. 2018a. Effects of Rice Straw Application on Methane Emission from Rice Paddy Fields. Journal of the Faculty of Agriculture, Kyushu University, 63(2): 387-392

Kim, S. H., Lee, J. H., Lim, J. S., Shinogi, Y., Lee, C. H and T. K, Oh. 2018b. Comparison of Methane Emissions on Soil Texture in Korean Paddy Fields. Journal of the Faculty of Agriculture, Kyushu University, 63(2): 393-397

Kongchum, M., Bollich, P. K., Hunnall, W. H, DeLaune, R. D and C. W, Lindau. 2006. Decreasing methane emission of rice by better crop management. Agron. Sustain. Dev., 26: 1-10

Liou, R., Huang, S., Lin, C, and S, Chen. 2003. Methane Emission from Fields with Three Various Rice Straw Treatments in Taiwan Paddy Soils. Joumal of Environmental Science and Health, Part B, 38(4): 511-527

Liu, E., Yan, C., Mei, X., He, W., Bing, S., Ding, L, Liu, Q., Liu, S and T, Fan. 2010. Long-term effect of chemical fertilizer, straw, and manure on soil chemical and biological properties in northwest China. Geoderma. 158(3): 173-180

Liu, G., Ma, J., Yang, Y., Yu, H., Zhang, G. and H, Xu. 2019. Effects of Straw Incorporation with a Microbial Inoculant on Nitrous Oxide and Methane Emissions from a Wheat-Rice Rotation System. Pedosphere. 29(2): 204-215

Luyima, D., Lee, J. H., An, J. Y., Kwon, O. S., Park, S. Y., Lee, S. J. Park, S. Y., Shinogi, Y., Park, K. W and Oh, T. K. 2019. Impact of Synchronizing the Application of Different Biochar Organic Fertilisers with NPK on Soil Chemical Properties and Growth of Leek (Allium ampeloprasum). Journal of the Faculty of Agriculture, Kyushu University, 64(1): 47-53

Naser, H. M., Nagata, O., Tamura, S, and R. Hatano. 2007. Methane emissions from five paddy fields with different amounts of rice straw application in central Hokkaido, Japan. Soil Science and Plant Nutrition, 53(1): 95-101

NDEP, 2003. The Nevada Handbook for Agricultural Open 
Burning. Nevada Division of Environmental Protection (NDEP), Las Vegas, USA

Neue, H. U., Wassmann, R., Lantin, R. S., Alberto, M. C. R., Aduna, J. B and A. M. Javellana. 1996. Factors affecting methane emission from rice fields. Atmospheric Environment, $\mathbf{3 0}(10$ 11): $1751-1754$

NIAST (National Institute of Agricultural Science and Technology) 2000 Analytical methods of soil and plant. RDA. Korea

Power, J., Koerner, P., Doran, J and W, Wilhelm. 1998. Residual effects of crop residues on grain production and selected soil properties. Soil Science Society of America Journal. 62(5): 1393-1397

Roldán, A., Caravaca, F., Hernández, M., Garcia, C., Sánchez-Brito, C., Velásquez M and M. Tiscareno. 2003. No-tillage, crop residue additions, and legume cover cropping effects on soil quality characteristics under maize in Patzcuaro watershed (Mexico). Soil and Tillage Research, 72(1): 65-73

Rolston, D. E. 1986. Methods of Soil Analysis: Part 1-Physical and Mineralogical Methods, Soil Science Society of America, Madison. pp. 1103-1119

Sass, R. L., Fisher, F. M., Harcombe, P. A and F. T, Turner. 1990. Methane production and emission in a Texas rice field. Global Biogeochem. Cycles, 4: 47-68

Schütz, H., Holzapfel-Pschorn, A., Conrad, R., Rennenberg, H and W. Seiler. 1989. A 3-year continuous record on the influence of daytime, season and fertilizer treatment on methane emission rates from an Italian rice paddy. J. Geophys.Res. Atmos., 94: 16 405-16 416

Singh, S., Singh, J. S., Kashyap, A. K. 1999 Methane flux from irrigated rice fields in relation to crop growth and $\mathrm{N}-$ fertilization. Soil Biol, Biochem., 31: 1219-1228

Smith, J., Papendick, R., Bezdicek, D., Lynch, J and Jr, Metting.
1992. Soil organic matter dynamics and crop residue management. Soil microbial ecology: applications in agricultural and environmental management. 65-94

Tang, S. R. Cheng, W., Hu, R., Guigue, J., Kimani, S. M., Tawaraya, $\mathrm{K}$ and $\mathrm{Xu}$. 2016. Simulating the effects of soil temperature and moisture in the off-rice season on rice straw decomposition and subsequent $\mathrm{CH}_{4}$ production during the growth season in a paddy soil. Biol. Fert. Soils., 52: 739-748

Tariq, A., Vu, Q. D., Jensen, L. S., de Tourdonnet, S., Sander, B. O., Wassmann, R., Mai, T. V and A, de Neergaard. 2017. Mitigating $\mathrm{CH}_{4}$ and $\mathrm{N}_{2} \mathrm{O}$ emissions from intensive rice production systems in northern Vietnam: Efficiency of drainage patterns in combination with rice residue incorporation. Agriculture, Ecosystems and Environment, 249: 101-111. doi:10.1016/j. agee.2017.08.011

Wanga, W., Lai, D. Y. F., Sardans, j., Wanga, C., Dattaf, A., Pana, T., Zenga, C., Bartrons, M and J, Penuelas. 2015. Rice straw incorporation affects global warming potential differently in early vs late cropping seasons in South eastern China. Field Crops Research, 18: 42-51

Webb, J., Hutchings, N and B, Amon. 2009. Field Burning of Agricultural Wastes. European Environment Agency (EEA), Copenhagen, pp. 1e14. EMEP/EEA Emission Inventory Guidebook

Wei, T., Zhang, P., Wang, K., Ding, R., Yang, B., Nie, J., Jia, Z and Q, Han. 2015. Effects of Wheat Straw Incorporation on the Availability of Soil Nutrients and Enzyme Activities in Semiarid Areas. PLOS ONE, 10(4): e0120994. doi: 10.1371/journal. pone.0120994

Yagi, K and K, Minami. 1990: Effect of organic matter application on methane emission from some Japanese rice fields. Soil Sci. Plant Nutr., 36(4): 599-610 